\title{
Effects of low temperature acclimation on photosynthesis in three Chilean Proteaceae
}

\author{
Efectos de la aclimatación a baja temperatura sobre la fotosíntesis de tres proteáceas \\ chilenas
}

\author{
MAURICIO CASTRO-ARÉVALO ${ }^{1}$, MARJORIE REYES-DÍAZ $^{1,2 *}$, MIREN ALBERDI $^{3,2}$, \\ VALERIA JARA-RODRÍGUEZ ${ }^{1}$, CAROLINA SANHUEZA ${ }^{1}$, LUIS J. CORCUERA ${ }^{1} \&$ LEÓN A. BRAVO $^{1}$
}

\author{
${ }^{1}$ Laboratorio de Fisiología Vegetal, Departamento de Botánica, Universidad de Concepción, \\ Casilla 160-C, Concepción, Chile \\ ${ }^{2}$ Dirección actual: Instituto de Agroindustria y Departamento de Ciencias Químicas, Facultad de Ingeniería, Ciencias y \\ Administración, Universidad de La Frontera, Casilla 54-D, Temuco, Chile \\ ${ }^{3}$ Instituto de Botánica, Facultad de Ciencias, Universidad Austral de Chile, Casilla 567, Valdivia, Chile \\ *e-mail for correspondence: reyesm@ufro.cl
}

\begin{abstract}
Embothrium coccineum, Gevuina avellana, and Lomatia ferruginea grow in habitats contrasting in temperature and light intensity. Embothrium coccineum is a pioneer species that establishes itself in open sites completely exposed to variable sunlight and temperature. Gevuina avellana is usually found in more protected sites. Lomatia ferruginea regenerates under the canopy in sites with low thermal oscillations and high humidity. In order to establish an association of their habitats with functional attributes of each species, we studied their photosynthetic responses to temperature and light intensity. We expected that E. coccineum, which grows at full sun, is able to acclimate much better its photosynthetic apparatus to different temperatures than the shade tolerant L. ferruginea and the semi-shade tolerant G. avellana. One group of plants of each species containing six individuals each was subjected to $4{ }^{\circ} \mathrm{C}$ (cold-acclimated plants). Another group with the same number of individuals was subjected to $20^{\circ} \mathrm{C}$ (non-acclimated plants). In non-acclimated plants of $E$. coccineum, the photosynthetic rate as measured by $\mathrm{O}_{2}$ evolution presented its maximum at $30{ }^{\circ} \mathrm{C}(16.5 \mu \mathrm{mol}$ $\mathrm{O}_{2} \mathrm{~m}^{-2} \mathrm{~s}^{-1}$ ) with an optimum between 20 and $35{ }^{\circ} \mathrm{C}$, while in $G$. avellana and L. ferruginea the highest photosynthetic rate $\left(\sim 13 \mu \mathrm{mol} \mathrm{O} \mathrm{m}^{-2} \mathrm{~s}^{-}\right)$was obtained at $25^{\circ} \mathrm{C}$. Cold acclimation significantly reduced the photosynthetic rates of the investigated species. The $\mathrm{Q}_{10}$ for $\mathrm{O}_{2}$ evolution decreased significantly in coldacclimated E. coccineum and G. avellana but not in L. ferruginea. The fluorescence parameters of PSII showed that E. coccineum presents a higher effective quantum yield (ФPSII) at both growth temperatures. Photochemical quenching (qP) was more affected by the photosynthetic photon flux density (PPFD) in $L$. ferruginea than in the other species. Lomatia ferruginea presented the highest non-photochemical quenching (NPQ) at lower PPFD. Thus, the photosynthetic apparatus of each species presents functional differences according to the characteristics of light availability and temperature changes of their habitats.
\end{abstract}

Key words: Proteaceae, cold acclimation, photosynthetic oxygen evolution, photochemical efficiency of PSII.

\section{RESUMEN}

Embothrium coccineum, Gevuina avellana y Lomatia ferruginea crecen en hábitat contrastantes en temperatura e intensidad lumínica. Embothrium coccineum es una especie pionera que se establece en sitios abiertos, completamente expuestos a luminosidad y temperatura variables. Gevuina avellana se encuentra usualmente en sitios más protegidos. Lomatia ferruginea regenera bajo el dosel en sitios con bajas oscilaciones térmicas y alta humedad. Con el objetivo de establecer una asociación de los hábitats que ocupan estas especies y los atributos funcionales de cada una de ellas, se estudió las respuestas fotosintéticas a la temperatura e intensidad lumínica. Un grupo de plantas de cada especie (seis individuos por especie) se aclimataron a $4{ }^{\circ} \mathrm{C}$ (plantas aclimatadas al frío). Otro grupo con el mismo número de individuos fue mantenido a $20{ }^{\circ} \mathrm{C}$ (plantas no aclimatadas al frío). Plantas no aclimatadas de E. coccineum, presentaron una tasa fotosintética máxima, medida como evolución de $\mathrm{O}_{2}$, a $30{ }^{\circ} \mathrm{C}\left(16,5 \mu \mathrm{mol} \mathrm{O}_{2} \mathrm{~m}^{-2} \mathrm{~s}^{-1}\right)$ con un óptimo entre 20 y $35^{\circ} \mathrm{C}$, mientras que en G. avellana y L. ferruginea la mayor tasa fotosintética $\left(\sim 13 \mu \mathrm{mol} \mathrm{O}_{2} \mathrm{~m}^{-2} \mathrm{~s}^{-1}\right)$ se obtuvo a $25^{\circ} \mathrm{C}$. La aclimatación al frío redujo significativamente las tasas fotosintéticas de las especies. El $\mathrm{Q}_{10}$ para la evolución de $\mathrm{O}_{2}$ fue similar en las tres especies en el estado no aclimatado al frío. La aclimatación al frío disminuyó $\mathrm{Q}_{10}$ en E. coccineum y G. avellana, pero permaneció invariable en L. ferruginea. Los 
parámetros de fluorescencia del PSII mostraron que E. coccineum presentó un mayor rendimiento cuántico efectivo del PSII (ФPSII) a ambas temperaturas crecimiento. El apagamiento fotoquímico (qP) fue más afectado por la densidad de flujo fotónico fotosintético (PPFD) en L. ferruginea que en las otras especies . Lomatia ferruginea presentó el mayor apagamiento no fotoquímico (NPQ) a una baja PPFD. Por lo tanto, el aparato fotosintético de cada especie presenta diferencias funcionales de acuerdo a las características de disponibilidad lumínica y cambios de temperatura de sus hábitat.

Palabras clave: Proteaceae, aclimatación al frío, evolución fotosintética de oxígeno, eficiencia fotoquímica del PSII.

\section{INTRODUCTION}

One of the most important factors that limit development and distribution of plants is temperature, because different physiological processes have different temperature optima for their functioning (Larcher 1995). Optimal temperature for gas exchange is known to vary among species (Berry \& Björkman 1980, Badger et al. 1982, Ferrar et al. 1989, Makino et al. 1994, Hikosaka et al. 1999, Yamasaki et al. 2002). Low temperature decreases all biochemical processes including photosynthesis, respiration and protein synthesis (Hopkins 1999). This is due to the sensibility of cellular membranes to low temperature, independently of the damage that may occur due to intracellular formation of ice nuclei, which is usually lethal (Alberdi \& Corcuera 1991). Plants growing in different environments have different optima for photosynthesis, with plants in colder environments having lower temperature optima than those in warmer climates (Ngugi et al. 2003). Furthermore, photosynthesis plasticity in response to temperature is decisive for the success of a species in different environments and microclimates (Cabrera 2002).

Embothrium coccineum J. R. et G. Forster, Gevuina avellana Mol. and Lomatia ferruginea (Cav.) R. Br. are woody species of Proteaceae that prosper in different biotopes along the latitudinal and altitudinal gradient in the forests of the southern tip of South America. Embothrium coccineum and L. ferruginea present the widest and most southerly latitudinal distribution ( 35 to $56^{\circ} \mathrm{S}$ and $35^{\circ} 30^{\prime}$ to $52^{\circ} \mathrm{S}$ ), respectively, whereas $G$. avellana has a narrower distribution (33 to $45^{\circ} \mathrm{S}$ ) (Rodríguez et al. 1983). In addition to the differences in distribution, other important characteristics of ecological and/or physiological nature exist among these species.
Embothrium coccineum is a pioneer sun plant that colonizes open areas after natural or anthropic disturbance events, where it grows quickly forming dense stands. Gevuina avellana grows in temperate habitats and although it can grow directly exposed to sun, it needs some protection under other trees in the coldest biotopes. The best biotope for $L$. ferruginea presents small thermal oscillations and high environmental humidity. These species differ in their pioneer or successional role because they occupy different habitats varying in their exposition to light and temperature.

In plants, high radiation levels may cause photoinhibition of photosynthesis and photooxidative destruction of the photosynthetic apparatus (Osmond 1994). The exposure of plants to low temperature produces adverse effects on metabolic functions and one of the sensitive processes is photosynthesis (Larcher 1995). Species that are sensitive to cool temperature have a tendency to exhibit photoinhibition of photosynthesis when they are exposed to low temperature, even at moderate light intensity. On the other hand, species that are able to acclimate to low temperature are much less sensitive to low temperature-induced photoinhibition (Alves et al. 2002). We studied the effects of temperature on the photosynthesis of three species of the Proteaceae that differ in their biotopes preferences. The study by Read \& Hill (1985) about Nothofagus species and the present study are the first studies performed in species of the Chilean temperate rain forest on the relationship between temperature acclimation of photosynthesis and their habitats. It is postulated that E. coccineum, which grows at full sun, is able to acclimate its photosynthetic apparatus much better to different temperatures than the shade tolerant L. ferruginea and the semi-shade tolerant $G$. avellana. 


\section{MATERIAL AND METHODS}

\section{Experimental design}

One year-old seedlings of the three species were collected from the field in Katalapi Park (Pichiquillaipe), Décima Región, Chile, in winter. Seedlings were transferred to pots filled with soil from their habitats and maintained in climatic chambers for six months. Then, one group of plants of each species was maintained for two months at $20{ }^{\circ} \mathrm{C}$ (non-acclimated), 14:10 h day:night photoperiod, with a photosynthetic photon flux density (PPFD) of 200-250 mmol photons $\mathrm{m}^{-2} \mathrm{~s}^{-1}$ at the top of canopy and a relative humidity of $85 \%$. Another group of plants of the investigated species was maintained for the same period at 4 ${ }^{\circ} \mathrm{C}$ (cold-acclimated) at the same photoperiod and PPFD. The light source consisted of coolwhite fluorescent tubes F-40CW (General Electric, Charlotte, NC, USA). Seedlings were irrigated once a week and fertilized with Phostrogen (Solaris, Buckingghamshire, United Kingdom) using $0.2 \mathrm{~g} \mathrm{~L}^{-1}$ once every two weeks.

\section{Photosynthesis (oxygen evolution)}

Photosynthesis determined as oxygen evolution $(\mathrm{Pn})$ was measured in leaf discs of each species with a gas phase oxygen electrode unit, using a Model LD2/3 oxygen electrode chamber and the PC operated oxygen electrode control unit, Oxylab (Hansatech Instruments Ltd. King's Lynn, Norfolk, England). Measurements were performed in non-acclimated $\left(20{ }^{\circ} \mathrm{C}\right)$ and coldacclimated $\left(4{ }^{\circ} \mathrm{C}\right)$ plants at different temperatures between $5-40{ }^{\circ} \mathrm{C}$ controlled by a circulating water bath (Thermo Haake K15, Electron Corporation, Germany) and at a light irradiance of $250 \mu \mathrm{mol}$ photons $\mathrm{m}^{-2} \mathrm{~s}^{-1}$, obtained from the light saturation curves, measured as mentioned below. A Leaf disc of $10 \mathrm{~cm}^{-2}$ was put inside of LD2/3 measuring chamber and adapted for $10 \mathrm{~min}$ to each temperature. Measurements were performed at saturating $\mathrm{CO}_{2}$, obtained by adding a couple of drops of $1 \mathrm{M}$ carbonate/bicarbonate buffer at $\mathrm{pH}$ 9 into the measurement chamber. Light saturation levels for each species were obtained from photosynthesis light response curves made with nine irradiance values over the range of 0-800 $\mu \mathrm{mol}$ photons $\mathrm{m}^{-2} \mathrm{~s}^{-1}$ given by an array of red light emitting diodes (Model LH36/2R, Hansatech Instruments Ltd., King's Lynn, Norfolk, England).

The temperature dependence of photosynthesis, measured as the rate of oxygen evolution $\left(\mathrm{P}_{\mathrm{n}}\right)$, was estimated by calculating the temperature coefficient $\left(\mathrm{Q}_{10}\right)$ for each species and treatments. $\mathrm{Q}_{10}$ is the empirically measured change in the rate of a reaction for an alteration in temperature of $10{ }^{\circ} \mathrm{C}$ (Mohr \& Schopfer 1995). The dependence of the reaction constant (k) upon temperature ( $\mathrm{T}$ ) could be described by the Arrhenius equation: $\ln \mathrm{k}=\operatorname{lnk}_{0}-\mathrm{A} / \mathrm{R} * \mathrm{~T}$, where $\mathrm{k}_{0}$ and $\mathrm{A}$, are temperature dependent. Arrhenius constants were empirically determined: $\mathrm{R}$ is the universal gas constant. There is a linear relation between $\ln \mathrm{k}$ and $\mathrm{T}^{-1}$ following first equation. From the graphical presentation of the function $\ln \mathrm{k}=-\left(\mathrm{AR}^{-1}\right) \mathrm{T}^{-1}$ $+\ln \mathrm{k}_{0}$ (which correspond to $\mathrm{y}=-\mathrm{ax}+\mathrm{b}$ ), A and $\mathrm{k}_{0}$ can be calculated. Substituting $\mathrm{k}$ for net photosynthesis rate $\left(\mathrm{P}_{\mathrm{n}}\right)$ and considering that $\mathrm{A} /$ $\mathrm{R}$ is the slope of the curve $\ln \mathrm{P}_{\mathrm{n}}$ versus $\mathrm{T}^{-1}, \mathrm{Q}_{10}$ was obtained in the following equation: $\ln \mathrm{Q}_{10}=$ $\mathrm{A} / \mathrm{R} *(1 / \mathrm{T}-1 / \mathrm{T}+10)($ Mohr \& Schopfer 1995).

\section{Fluorescence parameters}

Fluorescence signals were measured by a pulse-amplitude modulated fluorometer of attached non shaded leaves (FMS 2, Hansatech Instruments Ltd., United Kingdom). The protocol of Reyes-Díaz et al. (2005) was followed. Non-acclimated and cold-acclimated leaves of the three species were dark adapted for $30 \mathrm{~min}$ (to obtain open reaction centers) with leaf-clips provided with a mobile shutter plate. Then the fiber-optic and its fiber-optic adapter were fixed to a controlled temperature chamber $\left(20\right.$ or $\left.4{ }^{\circ} \mathrm{C}\right)$, where the sample was placed and light pulses were applied. The minimal fluorescence $\left(\mathrm{F}_{\mathrm{o}}\right)$ was determined by applying a weak modulated light $(0.4 \mu \mathrm{mol}$ photons $\mathrm{m}^{-2} \mathrm{~s}^{-1}$ ) and maximal fluorescence (Fm) was induced by a short pulse $(0.8 \mathrm{sec})$ of saturating light $\left(9,000 \mu \mathrm{mol}\right.$ photons $\left.\mathrm{m}^{-2} \mathrm{~s}^{-1}\right)$. Fluorescence signals were followed until steady state level of fluorescence (Fs) was reached at different actinic light levels. To obtain Fm' (maximal fluorescence during illumination) a pulse of $9,000 \mu \mathrm{mol}$ photons $\mathrm{m}^{-2} \mathrm{~s}^{-1}$ was used. Fo', the minimal level of 
fluorescence, was determined after turning the actinic light off and immediately a $2 \mathrm{sec}$ far red (FR) pulse was applied. In this paper, the data of $\mathrm{F}_{\mathrm{v}} / \mathrm{F}_{\mathrm{m}}=$ variable fluorescence/maximal fluorescence, where $F_{\mathrm{v}}=\left(\mathrm{F}_{\mathrm{m}}-\mathrm{F}_{\mathrm{o}}\right)$ (maximal fluorescence - minimal fluorescence) and $\phi \mathrm{PSII}=\mathrm{F}_{\mathrm{m}}{ }^{\prime}-\left(\mathrm{F}_{\mathrm{s}} / \mathrm{F}_{\mathrm{m}}{ }^{\prime}\right)$ were used as indicators of the maximal and effective quantum yield of the PSII, respectively (Genty et al. 1989). Photochemical quenching (qP) was calculated as: $\mathrm{qP}=\left(\mathrm{F}_{\mathrm{m}}{ }^{\prime}-\mathrm{F}_{\mathrm{s}}\right) /\left(\mathrm{F}_{\mathrm{m}}{ }^{\prime}-\mathrm{F}_{\mathrm{o}}{ }^{\prime}\right)$, and non photochemical quenching was calculated as: $\mathrm{NPQ}=\left(\mathrm{F}_{\mathrm{m}}-\mathrm{F}_{\mathrm{m}}{ }^{\prime}\right) / \mathrm{F}_{\mathrm{m}}{ }^{\prime}$ (Maxwell \& Johnson 2000).

The different actinic light were controlled by the light source of the FMSII apparatus and applied through an optic fiber. Light intensity at the leaf surface was calibrated using a LI250 light meter (Li-Cor).

Determinations of total carotenoids and chlorophylls $a$ and $b$ in leaf extracts

Leaf extracts of non-acclimated $\left(20{ }^{\circ} \mathrm{C}\right)$ and cold acclimated $\left(4{ }^{\circ} \mathrm{C}\right)$ plants were made using $0.10 \mathrm{~g} \mathrm{FW}$ with $5 \mathrm{ml}$ of ethanol $96 \%$ and 0.3 $\mathrm{mg} \mathrm{mL}^{-1}$ of $\mathrm{CaCO}_{3}$ in cold and dim light. Then the extracts were centrifuged for $3 \mathrm{~min}$ at $12000 \mathrm{rpm}$ (about 5,000 g) and $4{ }^{\circ} \mathrm{C}$. Absorbance was measured in aliquots of the supernatant at 470, 649 and $665 \mathrm{~nm}$ (Shimadzu UV-1203) according to the method proposed by Lichtenthaler \& Wellburn (1983).

\section{Statistical analyses}

Reported values correspond to the means of three replicates for pigment experiments, four replicates for fluorescence parameters and three replicates for photosynthesis. For determining the effect of temperature on $\mathrm{P}_{\max }$ of each species, we performed a one way ANOVA, followed by a Tukey test to identify those values with significant differences. From these differences the optimum temperature for each species was established. The data were also subjected to a two-way ANOVA (where the factors were species and temperature of acclimation) and a Tukey test for multiple comparisons. The analyses were performed with the software STATISTICA (version 6, Stat Soft Inc.). Differences between the values were considered significant at $\alpha=0.05$.

\section{RESULTS}

Effect of the temperature acclimation on photosynthesis rate $\left(\mathrm{P}_{\max }\right)$

Photosynthesis determinations obtained by oxygen evolution showed differences in the temperature for maximum photosynthesis between the non-acclimated and coldacclimated species (Fig. 1A and 1B). Nonacclimated plants of E. coccineum had their maximum photosynthesis $\left(\mathrm{P}_{\max }\right)$ at $30{ }^{\circ} \mathrm{C}(16.5$ $\mu \mathrm{mol} \mathrm{O} \mathrm{O}_{2} \mathrm{~m}^{-2} \mathrm{~s}^{-1}$ ), with an optimum between $20^{\circ}$ and $35{ }^{\circ} \mathrm{C}$ while in $G$. avellana and $L$. ferruginea the highest photosynthetic rate $(\sim 13$ umol $\mathrm{O}_{2} \mathrm{~m}^{-2} \mathrm{~s}^{-1}$ ) was obtained at $25{ }^{\circ} \mathrm{C}$. Statistically significant differences among the $\mathrm{P}_{\max }$ of non-acclimated E. coccineum and the other species were found $(\mathrm{P}<0.05)$. Differences in oxygen evolution were found between non-acclimated and cold-acclimated plants of the three species being lower the photosynthesis in cold acclimated than in not acclimated ones $(\mathrm{P}<0.05)$. Cold-acclimated $E$. coccineum showed two similar $\mathrm{P}_{\max }$ at $10{ }^{\circ} \mathrm{C}$ and $35^{\circ} \mathrm{C}$, whereas G. avellana $\mathrm{P}_{\max }$ was at 30 ${ }^{\circ} \mathrm{C}$, and L. ferruginea at $25^{\circ} \mathrm{C}$ (Fig. 1B). At this temperature L. ferruginea species showed the highest $\mathrm{P}_{\max }$ (around 2 fold-higher) with respect to the other species at the same temperature and 1.3 - and 1.7-fold higher than $\mathrm{P}_{\max }$ of $G$. avellana and E. coccineum respectively. Nonacclimated plants evidenced net oxygen consumption (respiration) at the lowest $\left(5^{\circ} \mathrm{C}\right)$ and at the highest $\left(40^{\circ} \mathrm{C}\right)$ temperature, whereas cold-acclimated plants showed net respiration only at $40{ }^{\circ} \mathrm{C}$ (Fig. 1A). In the non-acclimated state the highest rate of respiration at $5{ }^{\circ} \mathrm{C}$ was found in L. ferruginea $\left(-2.6 \mu \mathrm{mol} \mathrm{O}_{2} \mathrm{~m}^{-2} \mathrm{~s}^{-1}\right)$ and the lowest in E. coccineum $\left(-0.6 \mu \mathrm{mol} \mathrm{O}_{2}\right.$ $\left.\mathrm{m}^{-2} \mathrm{~s}^{-1}\right)(\mathrm{P}<0.05)$, while at $40{ }^{\circ} \mathrm{C}$ E. coccineum and $G$. avellana presented statistically significant higher respiration rates (around -3.3 $\left.\mu \mathrm{mol} \mathrm{O} \mathrm{O}_{2}^{-2} \mathrm{~s}^{-1}\right)$ than L. ferruginea $(-0.5 \mu \mathrm{mol}$ $\left.\mathrm{O}_{2} \mathrm{~m}^{-2} \mathrm{~s}^{-1}\right)(\mathrm{P}<0.05)$ (Fig. 1A). Nevertheless, cold acclimated $L$. ferruginea evidenced higher respiration rate $\left(-2.5 \mu \mathrm{mol} \mathrm{O}_{2} \mathrm{~m}^{-2} \mathrm{~s}^{-1}\right)$ than $E$. coccineum (around $-0.67 \mu \mathrm{mol} \mathrm{O}_{2} \mathrm{~m}^{-2} \mathrm{~s}^{-1}$ ) at 40 ${ }^{\circ} \mathrm{C}(\mathrm{P}<0.05)$ (Fig. 1B). A statistically significant interaction between the acclimation treatment and temperature for oxygen evolution was found for each species $(\mathrm{P}<0.001)$. Temperature coefficients $\left(\mathrm{Q}_{10}\right)$ of non- 


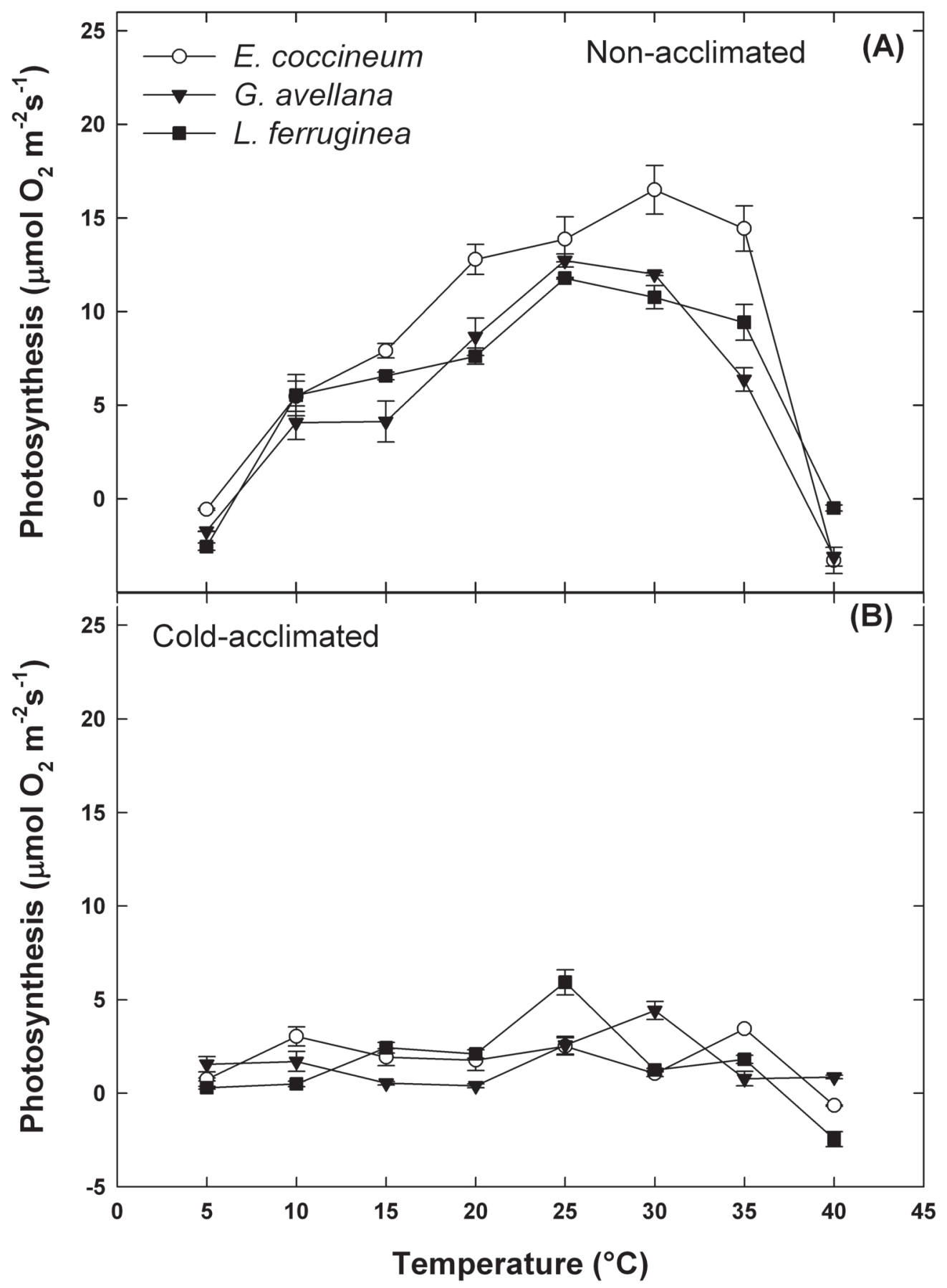

Fig. 1: Effect of cold acclimation on photosynthesis rate $\left(\mathrm{P}_{\max }\right)$ at various temperatures, for the investigated species. Measurements of $\mathrm{O}_{2}$ evolution were performed at saturating light and $\mathrm{CO}_{2}$. (A) non-acclimated and (B) cold-acclimated. Values are means $(n=4) \pm$ SE. Standard errors are not visible when their not exceeds the size of symbols.

Efecto de la aclimatación al frío sobre la tasa fotosintética $\left(\mathrm{P}_{\max }\right)$ de las especies investigadas a varias temperaturas. Mediciones de la evolución de $\mathrm{O}_{2}$ fueron realizadas a luz y $\mathrm{CO}_{2}$ saturantes. (A) no aclimatadas y (B) aclimatadas al frío. Valores corresponden a promedios $(n=4) \pm$ EE. Los errores estándar no se aprecian, cuando ellos no exceden el tamaño de los símbolos. 
acclimated plants were very similar among them. In contrast, in cold-acclimated plants $\mathrm{Q}_{10}$ decreased more than $23 \%$ with respect to the non-acclimated plants $(\mathrm{P}<0.05)$, with the exception of the shade-tolerant L. ferruginea (Table 1).

Effect of cold acclimation on light response of net photosynthesis and fluorescence parameters of PSII

Light response of net photosynthesis was distinctive for the non-acclimated studied species and consistent with light levels observed in their natural environments. Thus, in the non- acclimated state, the shade species L. ferruginea exhibited the highest dark respiration (-5.4 $\mu \mathrm{mol} \mathrm{O} \mathrm{O}_{2} \mathrm{~m}^{-2} \mathrm{~s}^{-1}$ at 0 PPFD) and the lowest maximum rate of net photosynthesis (3.8 $\mu \mathrm{mol} \mathrm{O} \mathrm{O}_{2} \mathrm{~m}^{-2} \mathrm{~s}^{-1}$ ) (Fig. 2A). G. avellana, the shade-semitolerant species, showed an intermediate value of maximum net photosynthesis $\left(10.4 \mu \mathrm{mol} \mathrm{O}_{2} \mathrm{~m}^{-2} \mathrm{~s}^{-1}\right)$ and $E$. coccineum the highest $\left(16 \mu \mathrm{mol} \mathrm{O}_{2} \mathrm{~m}^{-2} \mathrm{~s}^{-1}\right)$ (Fig. 2A). Cold acclimation reduced significantly (around in $80 \%$ ) the net photosynthesis of $E$. coccineum and $G$. avellana $(\mathrm{P}<0.05)$, but did not significantly affect photosynthesis of L. ferruginea (Fig. 2B). Dark respiration rates remained similar in both cold-acclimated and non-acclimated plants (Fig. 2A, 2B at 0 PPFD). Maximal and effective quantum yield of PSII (Fv/Fm and ФPSII, respectively), photochemical quenching (qP) and non-photochemical quenching (NPQ) in non-acclimated and cold-acclimated plants of the three studied species were measured (Fig. 3A-3H). Fv/Fm values of non-acclimated plants remained between 0.7 to 0.85 , at increasing light intensities, indicating an optimal physiological state (Björkman \& Demmig 1987, 1995), specially for $E$. coccineum and $G$. avellana, which had the highest values (Fig. 3A). Contrarily, in coldacclimated plants the $\mathrm{Fv} / \mathrm{Fm}$ values of $G$. avellana, decreased significantly above 500 $\mu \mathrm{mol}$ photons $\mathrm{m}^{-2} \mathrm{~s}^{-1}$ reaching photoinhibitory values (around 0.6) (Björkman \& Demmig 1987, 1995), whereas L. ferruginea and E. coccineum showed normal values during the light treatment (Fig. 3B). In the three species, $\Phi P S I I$ of non-acclimated plants decreased significantly at increased irradiances (Fig. 3A) Light response of DPSII of non-acclimated plants of $L$. ferruginea had a clear difference with respect to the other two species, showing the lowest light saturation and exhibiting the lowest values at high light indicating that this species would have the lowest electron transport rate (Fig. 3A). No major differences were observed in light response of $\Phi P S I I$ between $G$. avellana and E. coccineum. Cold acclimated plants showed a decrease in light saturation of QPSII of all species, being $G$. avellana which exhibited the most conspicuous decrease with light intensity, being around 0.15 even at $200 \mathrm{mmol}$ photons $\mathrm{m}^{-2} \mathrm{~s}^{-1}$ (Fig. 3B). Nonetheless, over $1,000 \mathrm{mmol}$ photons $\mathrm{m}^{-2} \mathrm{~s}^{-1}$ similar values were reached in all species. Nonacclimated plants of E. coccineum maintained the highest fraction of open reaction centers (higher qP) at irradiances from 200-1,000

\section{TABLE 1}

$\mathrm{Q}_{10}$ for non-acclimated and cold-acclimated plants of three Proteaceae. Values of $\mathrm{Q}_{10}$ are means ( $\mathrm{n}$ $=3) \pm$ SE. Different lower case letters indicate statistically significant differences $(P<0.05)$ between the treatments for each species. Different upper case letters show statistically significant differences $(\mathrm{P}<0.05)$ between species in the same treatment

$\mathrm{Q}_{10}$ de plantas no aclimatadas y aclimatadas al frío de las tres Proteáceas investigadas. Valores $\mathrm{Q}_{10}$ son promedios $(\mathrm{n}=3) \pm$

EE. Letras minúsculas diferentes muestran diferencias estadísticamente significativas $(\mathrm{P}<0,05)$ entre tratamientos para una misma especie. Letras mayúsculas diferentes muestran diferencias estadísticamente significativas entre las especies en un mismo tratamiento

\begin{tabular}{lccc}
\hline Treatment & \multicolumn{2}{c}{$\mathrm{Q}_{10}$} & L.ferruginea \\
\cline { 2 - 4 } & E. coccineum & G. avellana & $2.23 \pm 0.06^{\mathrm{aA}}$ \\
Non-acclimated & $2.26 \pm 0.05^{\mathrm{aA}}$ & $2.10 \pm 0.23^{\mathrm{aA}}$ & $2.31 \pm 0.30^{\mathrm{aC}}$ \\
Cold-acclimated & $1.74 \pm 0.07^{\mathrm{bBC}}$ & $1.42 \pm 0.16^{\mathrm{bB}}$ &
\end{tabular}




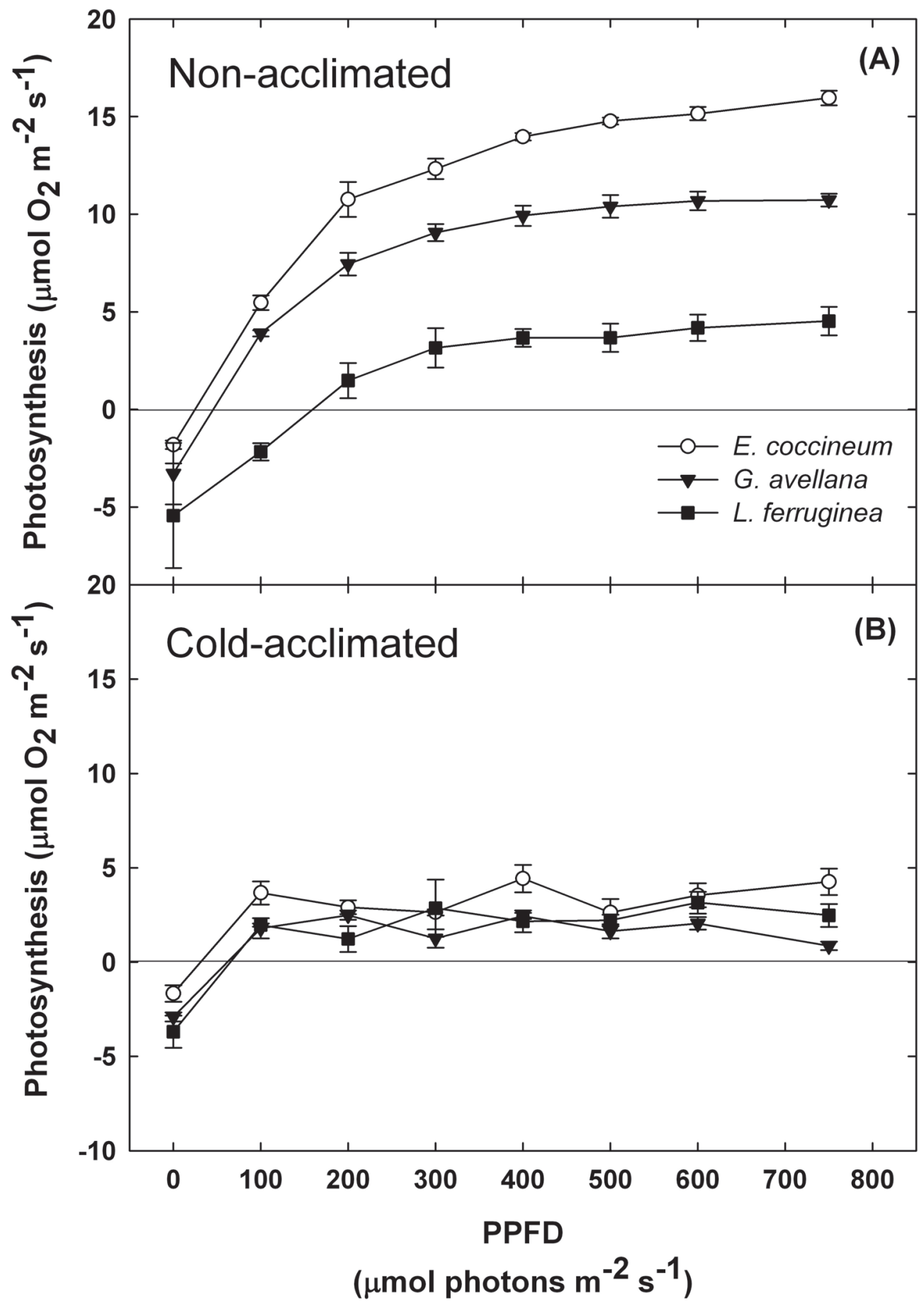

Fig 2: Light curves for oxygen evolution in non-acclimated (A) and cold-acclimated (B) plants of E. coccineum, $G$ avellana and L. ferruginea. Measurements were performed at eight different levels of PPFD; $(n=3 \pm S E)$. Standard errors are not visible when their magnitude does not exceed the size of symbols.

Curvas de luz para la evolución de Oxígeno en plantas no aclimatadas (A) y aclimatadas al frío (B) al aclimatadas de $E$. coccineum, $G$ avellana and L. ferruginea. Mediciones fueron realizadas a ocho niveles diferentes de densidad de flujo de fotones (PPFD); $(n=3 \pm E E)$. Los errores estándar no se aprecian, cuando ellos no exceden el tamaño de los símbolos. 


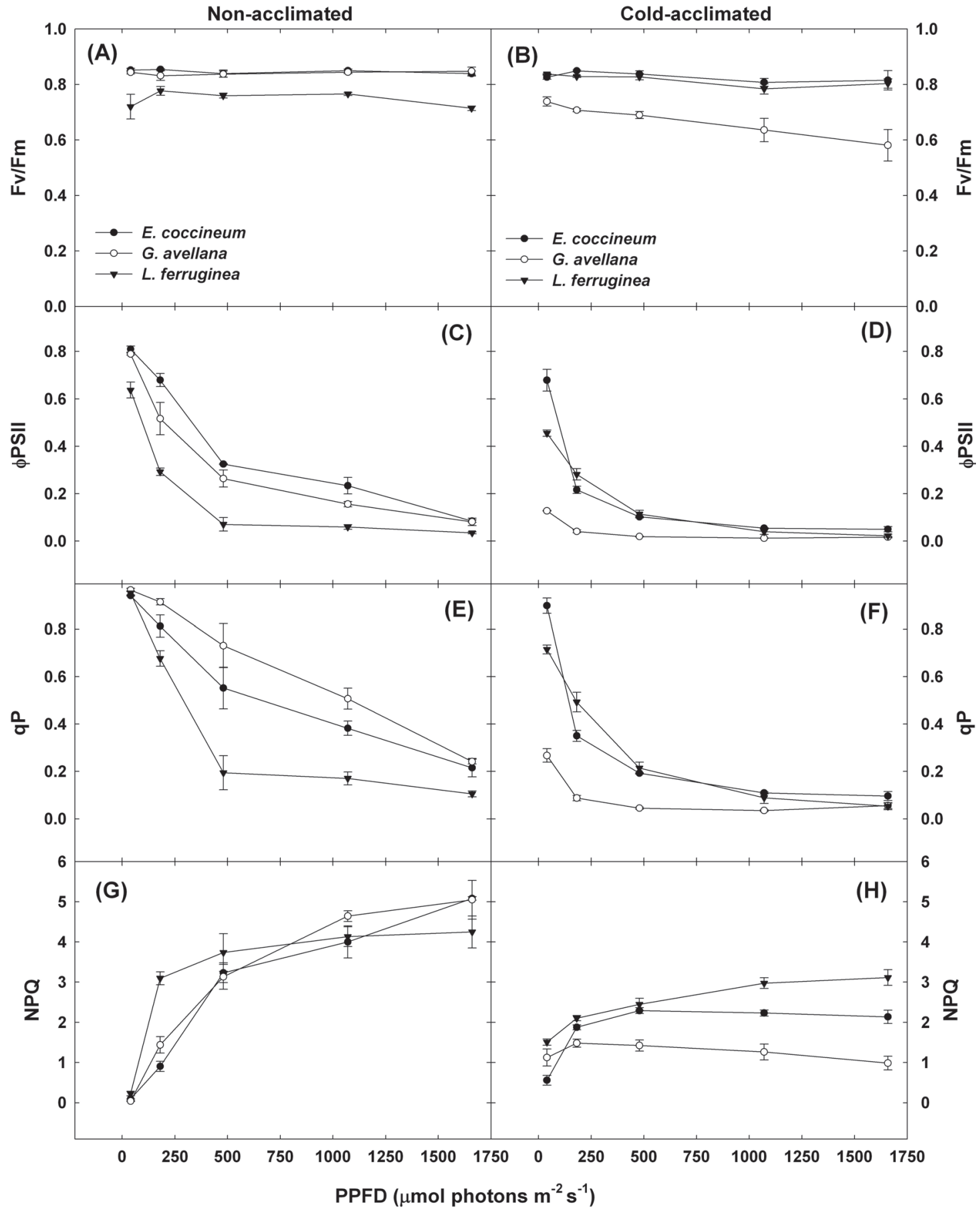

Fig. 3: Changes in the fluorescence parameters of the PSII in non-acclimated and cold-acclimated plants of Proteaceae at increasing light irradiances. PSII, photosystem II; Fv/Fm, maximum quantum yield of PSII (A, B); ФPSII, effective quantum yield of PSII (C, D); qP, photochemical quenching $(\mathrm{E}, \mathrm{F})$; NPQ, non photochemical quenching $(\mathrm{G}, \mathrm{H})$. Values are means $(\mathrm{n}=4 \pm \mathrm{SE})$. Standard errors are not visible when their magnitude does not exceed the size of symbols.

Cambios en los parámetros de fluorescencia del PSII en plantas de Proteaceae no aclimatadas y aclimatadas al frío a intensidades crecientes de luz. PSII, photosystem II; Fv/Fm, rendimiento cuántico máximo del PSII (A, B); ФPSII, rendimiento cuántico efectivo del PSII (C, D); qP, apagamiento fotoquímico (E, F); NPQ, apagamiento no fotoquímico (G, H). Valores son promedios $(n=4 \pm E E)$. Los errores estándar no se aprecian, cuando ellos no exceden el tamaño de los símbolos. 
mmol photons $\mathrm{m}^{-2} \mathrm{~s}^{-1}$, exhibiting no differences with $G$. avellana at $1,600 \mathrm{mmol}$ photons $\mathrm{m}^{-2} \mathrm{~s}^{-1}$ (Fig. 3C). Lomatia ferruginea was clearly the species that kept the lowest proportion of open reaction centers at the lowest irradiance $(\mathrm{qP}$ about 0.2 from $400 \mathrm{mmol}$ photons $\mathrm{m}^{-2} \mathrm{~s}^{-1}$ ahead), which indicates that even a low irradiance caused a significant excitation pressure of PSII in this species. Cold acclimation sharply reduced the light intensity at which $\mathrm{qP}$ was saturated for all species (Fig. 3D), being more obvious in G. avellana where its qP decreased to one third of the value observed in the non-acclimated plants even at $200 \mathrm{mmol}$ photons $\mathrm{m}^{-2} \mathrm{~s}^{-1}$. Cold acclimated plants of E. coccineum also decreased $\mathrm{qP}$ with respect to non-acclimated ones reaching about $50 \%$ of qP at about $200 \mathrm{mmol}$ photons $\mathrm{m}^{-2} \mathrm{~s}^{-1}$. Thermal dissipation of excess energy (NPQ) of non-acclimated plants was saturated at a lower irradiance $\left(400 \mathrm{mmol}\right.$ photons $\left.\mathrm{m}^{-2} \mathrm{~s}^{-1}\right)$ in $L$. ferruginea than in the other species (Fig. 2E). In this treatment, NPQ of G. avellana was saturated at about $1,100 \mathrm{mmol}$ photons $\mathrm{m}^{-2} \mathrm{~s}^{-1}$, while E. coccineum NPQ did not reach the saturation point. NPQ decreased in coldacclimated plants of all species with respect to non-acclimated plants (Fig. 3E and 3F). Interestingly, cold acclimated L. ferruginea maintained the highest capacity for heat dissipation and a slightly higher light saturation of NPQ than in non-acclimated state (Fig. 3F). NPQ of cold treated $G$ avellana and $E$. coccineum were readily saturated at 200 and $500 \mathrm{mmol}$ photons $\mathrm{m}^{-2} \mathrm{~s}^{-1}$ respectively.

\section{Variation in the content of pigments}

Because pigments are strongly associated with the photochemical performance and photosynthesis of plants, pigments contents of non-acclimated and cold-acclimated plants of the investigated species were studied. Nonacclimated plants of E. coccineum and $L$. ferruginea showed similar content in total chlorophylls and carotenoids, both in higher amounts than in G. avellana $(\mathrm{P}<0.05)$, (Table $2)$. These species showed a similar Chl $a / b$ ratio. A decrease in total chlorophyll contents (around 2-fold) was found in the coldacclimated individuals with respect the nonacclimated ones of the three species (Table 2). Total chlorophyll contents of cold acclimated species presented slightly differences between them. Embothrium coccineum and G. avellana $(\mathrm{P}<0.05)$ decreased noticeably their carotenoids contents with respect to nonacclimated plants, exhibiting a lower carotenoids/chlorophyll ratio and also a low Chl $a / b$ ratio than non-acclimated plants. Interestingly, cold-acclimated plants of $L$. ferruginea had a similar $\mathrm{Chl} a / b$ ratio and carotenoids/chlorophyll ratio than nonacclimated ones (Table 2). Independently of the treatment, carotenoid contents of L. ferruginea were the highest among the species. Statistically significant interactions between treatments and species were obtained for chlorophyll $a(\mathrm{P}=0.016)$, total chlorophyll ( $\mathrm{P}$ $=0.028)$ and total carotenoids $(\mathrm{P}=0.041)$.

\section{DISCUSSION}

Photosynthesis and respiration are strongly dependent on leaf temperature (Larcher 1995). These rates generally increase exponentially with temperature, although it has been demonstrated that after the photosynthetic parameters reach their maximum level, they decrease at higher temperature. The quantization of the photosynthetic response of individual species to temperature and light is important for comparing the plasticity or adaptability of different species to environmental conditions (Dungan et al. 2003). According to Krause (1994) photosynthetic rates diminished in cold-acclimated plants at 4 ${ }^{\circ} \mathrm{C}$ due to the highest proportion of inactive PSII centers caused by low temperature. This assumption is consistent with the lower proportion of open reaction centers $(\mathrm{qP})$ and lower light saturation of $\mathrm{qP}$ and $\Phi P S I I$ exhibited by cold acclimated plants of $G$. avellana and E. coccineum respect to nonacclimated ones (Fig. 3B and 3D). In addition, it has been reported that a higher dark respiration level in cold-acclimated plants may be associated with low levels of net photosynthesis (Graham \& Patterson 1982). However, in our study, this appears not to be the case because a slightly decreased or similar dark respiration was observed in cold acclimated and non-acclimated plants of the studied species (Fig. 2A and 2B). It has been reported that low growth temperature may 
decrease the activation energy of enzymatic reactions (Pereira 1995, Hikosaka et al. 2006) leading to a lower temperature requirement to reach maximum net photosynthesis. This was the case only for L. ferruginea and $E$. coccineum. Furthermore cold acclimated plants exhibited a higher photosynthesis stability at low temperature, preserving higher positive net photosynthesis at the lowest temperature than non-acclimated plants (Fig.1 A and 1B). Nonacclimated plants of E. coccineum presented a high photosynthesis rate accompanied by a wide optimum temperature range for photosynthesis. This is consistent with its typical character of sun plant (Weinberger 1974) and their widest latitudinal and altitudinal distribution. On the other hand, $G$. avellana and L. ferruginea present a more restricted optimum range of photosynthesis than E. coccineum, which is consistent with their more shade tolerance features and their lower latitudinal distribution for $G$. avellana but not for L. ferruginea which has a wider latitudinal distribution than $G$. avellana. Nonacclimated plants of $E$. coccineum showed significant differences with respect to the other species in photosynthesis level, but not in the cold-acclimated state, indicating that its photosynthetic apparatus is more sensitive to variations of temperature (Fig. 1A and 1B). Nonetheless, E. coccineum seems to be more adapted to low temperature than the other two species because it presents the highest photosynthesis rate, together with a high $\Phi$ PSII even at high light intensity, which demonstrated that it possesses a more efficient

TABLE 2

Effect of cold acclimation on pigments contents of the investigated Proteaceae. Chlorophyll $a$ (Chl $a)$, chlorophyll $b(\mathrm{Chl} b)$, total chlorophylls (Chla+Chl $b)$, relationship Chl $a$ and $b(\mathrm{Chl} a / \mathrm{Chl} b)$, total carotenoids (Car). Values are means $(n=3) \pm$ SE. Different lower case letters indicate statistically significant differences $(\mathrm{P}<0.05)$ between the treatments for each species and each pigment. Different upper case letters show statistically significant differences $(\mathrm{P}<0.05)$ between species in the same treatment for each pigment. Asterisks* indicate statistically significant differences between the treatments for the pigments or their ratios in each species

Efecto de la aclimatación al frío sobre el contenido de pigmentos en las Proteaceae investigadas. Chlorofila $a$ (Chla), chlorofila $b(\mathrm{Chl} b)$, clorofilas totales $(\mathrm{Chl} a+\mathrm{Chl} b)$, relación Chl $a$ y $b(\mathrm{Chl} a / \mathrm{Chl} b)$, carotenoides totales $(\mathrm{Car})$. Valores representan promedios $(n=3) \pm$ EE. Letras minúsculas differentes muestran diferencias estadísticamente significativas $(P$

$<0,05)$ entre tratamientos para cada pigmento. Letras mayúsculas diferentes muestran diferencias estadísticamente significativas entre las especies en un mismo tratamiento para cada pigmento. Asterisco* indica diferencias estadísticamente significativas para los pigmentos o sus radios entre los tratamientos, en cada especie

\begin{tabular}{|c|c|c|c|}
\hline \multirow[b]{2}{*}{ Pigment ( $\left.\mu \mathrm{g} \mathrm{g}^{-1} \mathrm{FW}\right)$} & \multicolumn{3}{|c|}{ Non-acclimated } \\
\hline & E. coccineum & G. avellana & L. ferruginea \\
\hline Chla & $1,075 \pm 30^{\mathrm{a} \mathrm{A}^{*}}$ & $595 \pm 68^{\mathrm{aB} *}$ & $972 \pm 53^{\mathrm{aA}^{*}}$ \\
\hline Chl $b$ & $681 \pm 57^{\mathrm{aA}}$ & $297 \pm 60^{\mathrm{aB}}$ & $594 \pm 60{ }^{a A^{*}}$ \\
\hline Chl $a+\mathrm{Chl} b$ & $1,756 \pm 58^{\mathrm{aA}^{*}}$ & $892 \pm 110^{\mathrm{aB}}$ & $1,567 \pm 105^{\mathrm{aA}^{*}}$ \\
\hline $\mathrm{Chl} a / \mathrm{Chl} b$ & $1.6 \pm 0.16^{\mathrm{aA}}$ & $2.1 \pm 0.34^{\mathrm{aA}}$ & $1.7 \pm 0.13 \mathrm{aA}$ \\
\hline Car & $159 \pm 20^{\mathrm{aA}^{*}}$ & $113 \pm 69^{a B^{*}}$ & $188 \pm 3 \mathrm{aA}^{*}$ \\
\hline \multirow[t]{2}{*}{ Car)/ Chl $a+$ Chl $b$} & $0.091 \pm 0.01^{\mathrm{aA}}$ & $0.129 \pm 0.01^{\mathrm{aAB}} *$ & $0.121 \pm 0.01^{\mathrm{aB}}$ \\
\hline & \multicolumn{3}{|c|}{ Cold-acclimated } \\
\hline Pigment $\left(\mu \mathrm{g} \mathrm{g}^{-1} \mathrm{FW}\right)$ & E. coccineum & G. avellana & L. ferruginea \\
\hline Chla & $338 \pm 70^{\mathrm{bA}}$ & $242 \pm 78^{\mathrm{bA}}$ & $467 \pm 37^{\mathrm{bA}}$ \\
\hline Chl $b$ & $284 \pm 74^{\mathrm{bA}}$ & $208 \pm 94^{\mathrm{aA}}$ & $274 \pm 47^{\mathrm{bA}}$ \\
\hline Chl $a+\operatorname{Chl} b$ & $622 \pm 138^{\mathrm{bA}}$ & $450 \pm 171^{\mathrm{bA}}$ & $741 \pm 83^{\mathrm{bA}}$ \\
\hline Chl $a /$ Chl $b$ & $1.3 \pm 0.2^{\mathrm{aA}}$ & $1.3 \pm 0.1^{\mathrm{bA}}$ & $1.8 \pm 0.2^{\mathrm{aA}}$ \\
\hline Car & $28 \pm 14^{\mathrm{bA}}$ & $43 \pm 5^{\mathrm{bA}}$ & $108 \pm 13^{\mathrm{bB}}$ \\
\hline Car)/ Chl $a+\mathrm{Chl} b$ & $0.061 \pm 0.03^{\mathrm{aA}}$ & $0.055 \pm 0.04^{\mathrm{bA}}$ & $0.151 \pm 0.03^{\mathrm{bB}}$ \\
\hline
\end{tabular}


photosynthetic apparatus than the other species. The high values of photosynthesis are consistent with the behavior of species that are often among the first to become established in mesic successional sequences (Dungan et al. 2003 ) as it occurs with E. coccineum. Moreover, this species can colonize highly unfavorable open habitats exposed to low temperature and high irradiance (Weinberger 1974, Alberdi \& Donoso 2004). Sun plants possess efficient energy dissipation mechanisms, including the xanthophylls cycle (carotenoids) (Loggini et al. 1999) and other physiological processes such as photorespiration and Mehler reaction (Niyogi et al. 1998, Pérez-Torres et al. 2004). During sunny days, the most abundant pigment of the xanthophyll cycle is zeaxanthin. Most plants require a higher photoprotective potential during the summer (Niyogi et al. 1998, Loggini et al. 1999). Also during the summer some plants present the lowest chlorophyll concentration, being capable of reducing the overexcitement, together with maximizing the xanthophyll cycle function (Björkman \& Deming-Adams 1995, Kyparissis et al. 2000). Shade species present frequently smaller total carotenoids and higher chlorophylls contents than sun plants (Adams et al. 2004). However, non-acclimated plants of $L$. ferruginea and $E$. coccineum showed higher chlorophyll content than the other investigated species. In coldacclimated plants, however, their contents decreased with respect to non-acclimated plants. This is most likely due to an acclimation response before the decrease in the enzymatic activity of the photosynthesis process (PérezTorres et al. 2004). Embothrium coccineum, G. avellana, and L. ferruginea decreased their total carotenoids content in cold-acclimated plants. However, L. ferruginea maintained a higher content of total carotenoids than the other species under the same condition. This could indicate that the exposition of this species to low temperature induced a major photosensitivity of its photosynthetic apparatus, and thereby a higher demand for photoprotection, with a higher NPQ, contrary to the other species (Fig. 3F). The decrease in pigments contents occurs as a consequence of cold-acclimation (Alves et al. 2002). It is notorious that $G$. avellana, in non-acclimated state, presents an intermediate behavior in the measured pigments parameters, while under cold-acclimation conditions it was more affected. A higher acclimation capacity would be advantageous when radiation or temperature suddenly increase having important effects on forest composition and regeneration (Oguchi et al. 2003). NPQ in cold-acclimated $E$. coccineum and L. ferruginea showed a strong increase from 0 to $200 \mu \mathrm{mol}$ photons $\mathrm{m}^{-2} \mathrm{~s}^{-1}$. This agrees with a decrease in $\mathrm{qP}$ and $\Phi P S I I$, indicating a high saturation of the reaction centers at relatively low light intensities (Fig. 3). This was probably related to PSII photoprotective thermal energy dissipation of excess absorbed light (Colom et al. 2003). The saturation of $\Phi$ PSII, $\mathrm{qP}$ and NPQ at low irradiance in L. ferruginea explains why this plant is a shade-tolerant species. E. coccineum shows a light response in heat dissipation (NPQ) similar to the semi-shade tolerant species (Fig. 3E) and a higher level of photosynthesis (Fig. 2), thus confirming the higher capacity of E. coccineum to respond to environmental variations. Two different strategies for light utilization in relation to growth and cold acclimation have been described (Savitch et al. 2002). The first strategy consists in maintaining high levels of photosynthetic rates, no chlorophyll losses, and minimal NPQ. The second strategy shows general depression of photosynthesis, pigments losses, and high and sustained capacity for NPQ. In our case, the three species appear to belong to the second strategy, but with lower NPQ with respect to the non-acclimated species. It is also important to mention that $G$. avellana seems to be more affected by cold acclimation than the other species, which is corroborated by the low $\mathrm{Fv} / \mathrm{Fm}$ values.

It is well known that temperature decreases with increasing latitude and altitude (Bannister 2007). Cabrera et al. (1998) reported lower photosynthesis in species of the tropical high Andes distributed at higher altitudes with respect those located at lower ones. A similar behavior was found by Pipper et al. (2006) in Kageneckia angustifolia growing in the Chilean Andes at different altitudes.

In general, it appears that the photosynthetic apparatus of L. ferruginea is less plastic than the other two species. This is consistent with their habitat preferences, in which L. ferruginea, a shade tolerant plant with more restricted 
latitudinal distribution than E. coccineum, is usually protected from drastic environmental variations. In contrast, E. coccineum shows a much higher plasticity in its photosynthetic performance, which would be required by the greater changes in radiation and temperature of its habitats, located at the most southerly easterly, altitudinal and latitudinal distribution (Escobar et al. 2006). G. avellana and $L$. ferruginea are distributed at lower altitudes in the occidental sites of the Andes, with more equilibrated thermal regimes (Donoso et al. 2006, Donoso \& Utreras 2006). In general, the distribution of these species is concordant with their lower photosynthetic performance.

\section{ACKNOWLEDGMENTS}

The authors thank FONDECYT 1050640 for financial support and to Alexis Estay and Valeria Neira provided technical assistance. Sandra Gacitúa provided advice on statistical analyses of the data. Frida Piper helped with the literature review.

\section{LITERATURE CITED}

ADAMS WW, CR ZARTER, $V$ EBBERT \& B DEMMING-ADAMS (2004) Photoprotective strategies of overwintering evergreens. Bioscience 54: 41-49.

ALBERDI MH \& LJ CORCUERA (1991) Cold acclimation in plants. Phytochemistry 30: 3177-3184.

ALVES P, A MAGALHÀES \& P BARJA (2002) The phenomenon of photoinhibition of photosynthesis and its importance in reforestation. Botanical Review 68: 193-208.

ALBERDI M \& C DONOSO (2004) Variabilidad en Embothrium coccineum. In: Donoso C, Premoli A, Gallo L \& Ipinza R (eds) Variación intraespecífica en las especies arbóreas de los bosques templados de Chile y Argentina: 345-356. Editorial Universitaria, Santiago, Chile.

BADGER M, O BJÖRKMAN \& P ARMOND (1982) An analysis of photosynthetic response and adaptation to temperature in higher plants: Temperature acclimation in the desert evergreen (Nerium oleander L). Plant Cell \& Environment 5: 85-99.

BANNISTER P (2007) A touch of frost? Cold hardiness of plants in the southern Hemisphere. New Zealand Journal of Botany 45: 1-33.

BERRY J \& O BJÖRKMAN (1980) Photosynthetic temperature response and adaptation to temperature in higher plants. Annual Review of Plant Physiology 31: 491-543.

BJÖRKMAN O \& B DEMMING (1987) Photon yield of $\mathrm{O}_{2}$ evolution and chlorophyll fluorescence characteristics at $77 \mathrm{~K}$ among vascular plants of diverse origins. Planta 170: 489-504.
BJÖRKMAN O \& B DEMMING-ADAMS (1995) Regulation of photosynthetic light energy capture, conversion, and dissipation in leaves of higher plants. In: Schulze ED \& Caldwell MM (eds) Ecophysiology of photosynthesis: 17-47 SpringerVerlag, Berlin, Germany.

CABRERA HM, F RADA \& L CAVIERES (1998) Effects of temperature on photosynthesis of two morphological contrasting plant species along an altitudinal gradient in the tropical high Andes. Oecologia 114: 145-152.

CABRERA HM (2002) Ecophysiological responses of plants in ecosystems with Mediterranean-like climate and high mountain environments. Revista Chilena de Historia Natural 75: 625-637.

COLOM MR, E PINI PRATO \& R GIANNINI (2003) Chlorophyll fluorescence and photosynthetic response to light in 1-year-old needles during spring and early summer in (Pinus leucodermis). Trees-Structure \& Function 17: 207-210

DONOSO C, B ESCOBAR \& F MEDEL (2006) Gevuina avellana Mol. In: Donoso C (ed) Las especies arbóreas de los bosques templados de Chile y Argentina: 264-276. Marisa Cuneo Ediciones, Valdivia, Chile.

DONOSO C \& F UTRERAS (2006) Lomatia ferruginea (Cav.) R. Br. In: Donoso C (ed) Las especies arbóreas de los bosques templados de Chile y Argentina: 344-347. Marisa Cuneo Ediciones, Valdivia, Chile.

DUNGAN R, D WHITEHEAD \& R DUNCAN (2003) Seasonal and temperature dependence of photosynthesis and respiration for two co-occurring broad-leaved tree species with contrasting leaf phenology. Tree Physiology 23: 561-568.

ESCOBAR B, C DONOSO, C SOUTO, M ALBERDI \& A ZÚÑIGA (2006) Embothrium coccineum. In: Donoso C (ed) Las especies arbóreas de los bosques templados de Chile y Argentina: 233-245. Marisa Cuneo Ediciones, Valdivia, Chile.

FERRAR P, R SLATYER \& J VRANJIC (1989) Photosynthetic temperature acclimation in Eucalyptus species from diverse habitats and a comparison with (Nerium oleander). Australian Journal of Plant Physiology 16: 199-217.

GENTY B, JM BRIANTAIS \& NR BAKER (1989) The relationship between the quantum yield of photosynthetic electron transport and quenching of chlorophyll fluorescence. Biochimica et Biophysica Acta 990: 87-92.

GRAHAM D \& B PATTERSON (1982) Responses of plants to low, nonfreezing temperatures: proteins, metabolism, and acclimation. Annual Review of Plant Physiology 33: 347-372.

HIKOSAKA K, A MURAKAMI \& T HIROSE (1999) Balancing carboxylation and regeneration of ribulose-1,5-bisphosphate in leaf photosynthesis: temperature acclimation of an evergreen tree (Quercus myrsinaefolia). Plant Cell \& Environment 22: 841-849.

HIKOSAKA K, K ISHIKAWA, A BORJIG IDAI, O MULLER \& Y ONODA (2006) Temperature acclimation of photosynthesis: mechanisms involved in the changes in temperature dependence of photosynthetic rate. Journal of Experimental Botany 57: 291-302.

HOPKINS WG (1999) Introduction to plant physiology. Second edition. John Wiley \& Sons, New York, New York, USA. 512 pp.

KRAUSE GH (1994) Photoinhibition induced by low 
temperatures. In: Baker NR, Bowyer JR (eds) Photoinhibition of photosynthesis: from molecular mechanisms to the field: 331-348. BIOS Scientific Publishers Limited, city name, United Kingdom.

KYPARISSIS A, P DRILIAS \& Y MANETAS (2000) Seasonal fluctuations in photoprotective (xanthophyll cycle) and photoselective (chlorophylls) capacity in eight Mediterranean plant species belonging to two different growth forms. Australian Journal of Plant Physiology 27: 265-272.

LARCHER W (1995) Photosynthesis as a tool for indicating temperature stress events. In: Schulze ED, Caldwell MM (eds) Ecophysiology of photosynthesis: 261-277 Springer-Verlag, Berlin, Germany.

LICHTENTHALER H \& A WELLBURN (1983) Determinations of total carotenoids and chlorophylls $\mathrm{a}$ and $\mathrm{b}$ of leaf extracts in different solvents. Biochemical Society Transactions 603: 591-592.

LOGGINI B, A SCARTAZZA, E BRUGNOLI \& F NAVARI-IZZO (1999) Antioxidative defense system, pigment composition, and photosynthetic efficiency in two wheat cultivars subjected to drought. Plant Physiology 119: 1091-1099.

MAKINO A, H NAKANO \& T MAE (1994) Effects of growth temperature on the responses of Ribulose 1,5- bisphosphate carboxylase, electron transport components, and sucrose synthesis enzymes to leaf nitrogen in rice, and their relationships to photosynthesis. Plant Physiology 105: 1231-1238.

MAXWELL K \& GN JOHNSON (2000) Chlorophyll fluorescence-a practical guide. Journal of Experimental Botany 51: 659-668.

MOHR H \& P SCHOPFER (1995) Plant physiology. Springer-Verlag, Berlin, Germany. 629 pp.

NGUGI M, M HUNT, D DOLEY, P RYAN \& P DART (2003) Photosynthetic light and temperature responses of (Eucalyptus cloeziana) and (Eucalyptus argophloia). Australian Journal of Botany 51: 573-583.

NIYOGI K, A GROSSMAN \& O BJÖRKMAN (1998) Arabidopsis mutants define a central role for the xanthophyll cycle in the regulation of photosynthetic energy conversion. Plant Cell 10: 1121-1134.

OGUCHI R, K HIKOSAKA \& T HIROSE (2003) Does the photosynthetic light-acclimation need change in leaf anatomy? Plant Cell \& Environment 26: 505-512.

Associate Editor: Thomas Kitzberger

Received October 25, 2007; accepted February 04, 2008
OSMOND CB (1994) What is photoinhibition? Some insights from comparisons of shade and sun plants. In: Baker NR \& Bowyer JR (eds) Photoinhibition of photosynthesis: from molecular mechanisms to the field: 1-24 BIOS Scientific Publishers Limited, city name, United Kingdom.

PEREIRA JS (1995) Gas exchange and growth. In: Schulze ED \& Caldwell MM (eds) Ecophysiology of photosynthesis: 147-181 Springer-Verlag, Berlin, Germany.

PÉREZ-TORRES E, A GARCÍA, J DINAMARCA, M ALBERDI, A GUTIÉRREZ, M GIDEKEL, A IVANOV, N HÜNER, L CORCUERA \& L BRAVO (2004) The role of photochemical quenching and antioxidants in photoprotection of (Deschampsia Antarctica). Functional Plant Biology 31: 731-741.

PIPER FI, LA CAVIERES, M REYES DÍAZ \& LJ CORCUERA (2006) Carbon sink limitation and frost tolerance control performance of the tree Kageneckia angustifolia D. Don (Rasaceae) at the tree line in central Chile. Plant Ecology 185: 29-39.

READ J \& RS HILL (1985) Photosynthetic response to light of Australian and Chilean species of Nothofagus and their relevance to the rainforest dynamics. New Phytologist 101: 731-742.

REYES-DÍAZ M, M ALBERDI, F PIPER, LA BRAVO \& CORCUERA, L.J. (2005). Low temperature responses of Nothofagus dombeyi (Mirb) Blume and Nothofagus nitida (Phil.) Krasser, two evergreen species from south central Chile. Tree Physiology. 25: 1389-1398.

RODRÍGUEZ R, O MATTHEI, M QUEZADA (1983) Flora arbórea de Chile. Editorial de la Universidad de Concepción, Concepción, Chile. 408 pp.

SAVITCH LV, ED LEONARDOS, M KROL, S JANSSON, B GRODZINSKI, NPA HUNER \& G ÖQUIST (2002) Two different strategies for light utilization in photosynthesis in relation to growth and cold acclimation. Plant Cell \& Environment 25: 761-771

WEINBERGER P (1974) Verbreitung and Wasserhaushalt araukano-patagonischer Proteaceen in Beziehung zu mikroklimastischen Faktoren. Flora 163: 251-264.

YAMASAKI T, T YAMAKAWA, Y YAMANE, H KOIKE, K SATOH \& S KATOH (2002) Temperature acclimation of photosynthesis and related changes in photosystem II electron transport in winter wheat. Plant Physiology 128:1087-1097. 
